Irena Matus

Uniwersytet $w$ Białymstoku

\title{
Trendy dekoracyjne podlaskich strojów i tkanin użytkowych w pierwszej połowie XX wieku na bazie zbiorów muzealnych „Baćkauszczyny”
}

Mitem jest przekonanie, że ludność wiejska, uboga, samowystarczalna, jeśli chodzi o produkcję tkanin i szycie ubiorów, długo odcięta od obowiązujących w innych kręgach wzorów, wytwarzała wyłącznie przedmioty proste, niewyszukane, za jedyne kryterium uważając ich praktyczne zastosowanie. Rękodzieło pozwalało wykazać się troską i o wizualną stronę wyrobów.

Przedmiotem prezentacji są tkaniny dekoracyjne i ubiory kobiece w zbiorach Muzeum „Baćkauszczyna” w Rybołach. Eksponaty zebrane zostały w większości na terenie jednej parafii, obejmującej wsie Pawły, Kaniuki, Ryboły, Wojszki, w przeszłości wsie hospodarskie, później królewskie, usytuowane na północnym brzegu Narwi. Muzeum „Baćkauszczyna" to przedsięwzięcie zorganizowane przez księdza Grzegorza i Antoninę Sosnów.

Wsie północno-wschodniej części Podlasia to teren zapóźniony w rozwoju gospodarczym, aż do początku lat 60 . XX wieku utrzymywała się tu gospodarka naturalna, głównie jako następstwo bieżeństwa - tragedii, która przedłużyła o parę dziesięcioleci taki stan rzeczy. Specyfika gospodarki naturalnej wywierała wpływ tak na wystrój izb, jak i trendy w wiejskiej modzie. Ogromne ubóstwo odcisnęło wyraźne piętno na charakterystycznym wzornictwie i zdobnictwie chłopskich strojów, zwłaszcza kobiecych, oraz oryginalnych i niepowtarzalnych tkaninach dekoracyjnych, zdobiących wnętrza domów. Spróbujmy przyjrzeć się zdobnictwu i swoistym kanonom mody, wyróżniającym podlaską kulturę tradycyjną w dobie jej renesansu, od końca lat 30. po 60. ubiegłego wieku. 


\section{Specyfika wystroju chłopskich wnętrz}

\section{Ręczniki}

Jednym z charakterystycznych detali dekoracyjnych wnętrz wiejskich chałup były ręczniki. Do końca lat 60 . XIX wieku pełniły uprzywilejowaną funkcję, zdobiły najważniejsze miejsce - pokut' - sakralną i nietykalną przestrzeń w chłopskiej izbie. Ręcznik stanowił ważny atrybut domowego ołtarza. Interesująco jawi się zwłaszcza rola rytualna i obrzędowa ręcznika, poprzestanę jednak na dekoracyjnej.

Ręczniki wieszane na ikony miały od 2 do 4 , a nawet 5 metrów długości i 40-60 centymetrów szerokości. Ich zdobienia nie były przypadkowe, kryjąc w sobie bogatą symbolikę. Techniki dekoracyjne podlaskich ręczników zmieniały się w poszczególnych okresach. Najstarsze pochodzą z początku XX wieku. Mają długość od 1,5 do 3 metrów, zdobione są haftem krzyżykowym bądź tkackim, zwanym wybieranym (perebory). Haft tkacki przypomina haft wykonany igłą. Haftowano nićmi w dwóch kolorach - czerwonym i czarnym, sporadycznie niebieskim. Kolor czerwony symbolizował życie, czerń przypominała o nieuchronnej śmierci. Na ikonę ręczniki z przewaga barwy czarnej wieszano w czasie adwentu i żałoby, czerwonej - w okresie paschalnym, Bożego Narodzenia, wesela w rodzinie.

W najstarszym zdobnictwie (do końca XIX wieku) dominowały wzory geometryczne, pojawiały się solarne detale zdobnicze, będące odbiciem ornamentyki czasów przedchrześcijańskich, jaka służyła przekazywaniu informacji, która przetrwała przez stulecia i jest wymownym dowodem roli ręcznika w czasach przedchrześcijańskich. Charakterystycznymi motywami zdobnictwa były detale geometryczne: romby, rozety, koła nawiązujące do mitologii pogańskiej ${ }^{1}$.

Na ogół dla motywów zdobnictwa charakterystyczna była prostolinijność, przejrzystość i jasność wzorów, spokojna rytmika identycznych powtarzających się elementów z zachowaniem symetrii. Motywy ściśle powiązane są z takimi ogólnie zrozumiałymi pojęciami, jak dobro, światło, życie, płodność. Przyjęły się one tak samo, jak znaki ognia, słońca, ziemi, nieba, wody czy światła. Cechą charakterystyczną jest niejednoznaczność motywów i ich ogromna mnogość. Konkretna jest symbolika, w pewnym stopniu zależna od umiejscowienia motywu w kompozycji wzoru, czy występował jako pojedyncza figura, czy też element ornamentalnej konstrukcji. Cechą

1 В. Фадзеева, Беларускі ручнік, Мінск 1994, s. 11-12. 
charakterystyczną jest nakładanie się motywów. Korzystano z prastarych wzorów - trójkąty, czworokąty, gwiazdy, rozety².

Ręczniki tkane w okresie międzywojennym miały przeważnie splot szachownicowy lub jodełkowy, potocznie zwany warkoczowym, a w gwarze czynowatym. Tego typu technika tkacka z jednej strony podnosiła trwałość tkaniny, z drugiej zaś jej dekoracyjność.

Barwne opakowania produktów przemysłu perfumeryjnego spowodowały, że upowszechniły się wzory florystyczne i zoomorficzne, pojawiły się scenki rodzajowe. Praktykowano cyryliczne napisy o charakterze religijnym, moralizatorskim, haftowano sentencje. W latach 30. XX wieku, a zwłaszcza w czasach powojennych, upowszechniło się kolorowe zdobnictwo ręcznika. Miejsce dwubarwnych haftów krzyżykowych zajęły wielobarwne motywy, przeważnie roślinne (kwiaty, liście, kiście winorośli, wazony z kwiatami) z elementami zoomorficznymi (koguty, gołębie czy pawie) wyszywane techniką atłaskową, zwaną haftem płaskim, w gwarze hładiooju. Bardziej dekoracyjne stało się także zakończenie ręcznika, z dłuższą i bogatszą koronką szydełkową, niekiedy dodatkowo wstawkami w środku. Największy renesans tego typu ręcznika przypada na Podlasiu na lata powojenne. Po drugiej wojnie światowej wieszano je już nie tylko na ikony, ale na obrazki, ślubne portrety, prezentowano same na oryginalnych wieszakach na ścianach.

\section{Makatki}

Pod koniec okresu międzywojennego w wiejskich chałupach, w miejsce obrazów, zawieszanych w mieszczańskich i szlacheckich domach, pojawiły się różnobarwne makatki. Zawieszano je w kuchni, alkierzu, izbie reprezentacyjnej. Przeznaczenie dyktowało rodzaj materiału, kolorystykę i kanony zdobnicze. Makatki kuchenne (umieszczane nad stołem kuchennym, bądź w kącie, gdzie stało wiadro z wodą) cechowała jednobarwność, dominował kolor niebieski, od błękitu aż po granat, rzadziej czerwien, fiolet, sporadycznie zieleń. Zdobione prostym wzorem sznureczkowym, głosiły sentencje gloryfikujące zgodę w rodzinie, wierność małżeńską (gdzie miłość i zgoda panuje tam szczęście swe gniazdko buduje), chwaliły talent kulinarny gospodyni, porządek i czystość, życzyły smacznego, witały nowy dzień, a zawieszane w alkierzu życzyły dobrej nocy. W zdobnictwie dominowały wzory florystyczne, gałązki i kiście winogron, liść dębu - symbole płodności, owoce, obok rodzimych pojawiały się także egzotyczne (ananas) - motywy

2 В. Лабачэўская, Повязь часоў - беларускі ручнік, Мінск 2002, s. 14-15. 
obfitości i dobrobytu. Makatki mówiły za pomocą symboli. Małżeństwo, domowe ognisko odzwierciedlała para ptaków, najczęściej gołębi, łabędzi, pawi oraz ptasie gniazdko, podobnie motywy roślinne układające się na kształt podkowy czy koła. Nawiązywały tematycznie do daru potomstwa, czasów dzieciństwa (częste motywy dzieci, domowego ptactwa, świata baśni). Rękodzielnictwo makatkowe z czasem zastąpiono fabrycznymi nadrukami, z zachowaniem tradycyjnej kolorystyki i tematyki.

Druga grupę stanowią makatki wielobarwne, zawieszane w alkierzu, a zwłaszcza w pokoju reprezentacyjnym. Najczęściej były wyszywane na samodziale wełnianym w ciemnej tonacji, przeważnie czarnym bądź szarym - lnianym. Charakteryzowała je bardzo szeroka paleta barw i ogromna inwencja twórcza autorek. Wyszywane haftem płaskim zwanym atłaskowym, sporadycznie skromnym sznureczkowym, barwnym kordonkiem, muliną, kolorową wełną bądź lancetą. Często u dołu zakończone frędzlami, rzadziej zdobiła je dookoła mereżka. Najczęściej w tej grupie makatek występował bukiet barwnych kwiatów w wazonie, koszyku, niekiedy związany wstążką. Miały one kształt prostokąta, kwadratu czy rombu. Tematem przewodnim zdobnictwa były elementy roślinne, zoomorficzne, postacie mityczne i baśniowe.

\section{Narzuty (płachty)}

Ważnym elementem dekoracyjnym a zarazem praktycznym były tkane na krosnach wełniane i lniane, ścielone na łóżka w święta i używane na co dzień, narzuty, zwane tu płachtami. Starsze, tzw. radiuszki, cechował geometryczny ornament z często powtarzanym motywem kwadratu i koła. Późniejsze, o kapowym wzorze ( $w$ perebory), były dwubarwne, o czarnej bądź białej, niekiedy szarej osnowie i kolorowym wątku. Wykonywano je do czasu pojawienia się fabrycznych kap. Początkowo praktykowano naturalne barwniki, które z czasem ustąpiły miejsca szerokiej palecie farb przemysłowych. Niezwykle dekoracyjną techniką zdobienia płacht było wyszywanie na wełnianej ciemnej, najczęściej w czarnej (celem lepszego wydobycia wzoru i barwy) tonacji kanwie. Spod ręki wiejskich artystek wychodziły arcydzieła, na których rozkwitały kolorowe kwiaty, spoglądały dumne pawie czy łabędzie. Wyszywano ciekawą techniką - stosując wełniane nici, jeszcze bardziej dekoracyjny efekt dawała błyszcząca lanceta. Warto zauważyć jeszcze inny, misterny sposób zdobienia. Na specjalnej ramie wiązano siatkę z lnianych, w naturalnym kolorze bądź farbowanych na ciemny kolor wełnianych, grubych nici, na której wyszywano jedo- lub wielobarwne wzory. Pod koniec lat siedemdziesiątych w miejsce dwubarwnych narzut pojawiły się wełniane, tę- 
czowe pasiaki, zmodyfikowane następnie w zygzakowate kilimy o ornamentyce geometrycznej. Wyróżniano dwa typy wzorów - płomykowy (zygzakowaty, zębaty oraz gwiaździsty). Pierwszy motyw cechowały haczykowate zęby osadzone na wieloboku, drugi typ składał się z gwiazd i wieloboków o schodkowych konturach ${ }^{3}$.

\section{Bielizna pościelowa i stołowa}

Dekoracyjna, odświętna, rzadko używana na co dzień, była chlubą, dodawała splendoru domowi i zaświadczała o zdolnościach i pracowitości gospodyni. Do czasu zaniku kultury tradycyjnej najdłużej utrzymującym się jej elementem były dekoracje łóżek w izbie reprezentacyjnej. Na zasłane starannie łóżko gospodynie układały piętrowo wyszywane haftem płaskim w motywy florystyczne i zoomorficzne poszewki. Zazwyczaj jako baza służyło już bawełniane płótno fabryczne. Na samej górze układano podobnie zdobioną poduszeczkę (jasieczek). W latach 70. ubiegłego wieku pojawiła się nowa technika zdobnicza bielizny pościelowej i stołowej - haft richelieu (riszelje). Z tak bogato zdobionych poduszek na co dzień rodzina nie korzystała, służyły one wyłącznie jako element dekoracyjny. Podobnie ścielony na stół w pokoju reprezentacyjnym obrus pełnił bardziej rolę dekoracyjną niż praktyczną.

\section{Chodniki}

Podłogi przykrywały tkane na krosnach połowiki, chodniki - tzw. szmaciaki, w kolorowe pocięte paski zużytych materiałów na lnianej osnowie lub takie, gdzie wątek i osnowa były lnianymi nićmi, własnoręcznie farbowanymi przez gospodynie i najbardziej ekskluzywne odświętne chodniki o wzorze kapowym ( $w$ perebory), dwukolorowe z nici lnianych, sporadycznie wełnianych.

\section{Detale zdobnicze typu pająki, firanki, kwiaty}

Wystroju wnętrza dopełniały barwne tzw. pająki, wykonane z kolorowej bibuły, niekiedy z dodatkiem lśniącej słomy, które swoimi odnogami obejmowały całą powałę izby. Charakterystycznym i obowiązkowym elementem wystroju izby były zawieszane w oknach misternie wycinane firaneczki

3 A. Troc-Sosna, Бачькаўшчьън. Muzeum Kultury Materialnej w Rybolach, Ryboły-Studziwody 2011, s. 63. 
z białej, gładkiej bibułki, z zachowaniem powtarzających się florystycznych, rzadziej zoomorficznych, motywów. Tych najmniej trwałych podlaskich ludowych oryginalnych arcydziełek zachowało się bardzo mało. Kiedy chałupa powiększyła się w okresie międzywojennym o izbę reprezentacyjną - weliku chatu, na stole pojawiły się wazony, w które wstawiały kobiety własnoręcznie wykonane $\mathrm{z}$ barwnej bibuły kwiaty.

\section{Od kultury tradycyjnej do współczesności}

Upadek kultury tradycyjnej odbił się negatywnie na wystroju wiejskich wnętrz. Charakterystyczne dla tego obszaru rękodzielnictwo, misterne arcydzieła, którymi do niedawno jeszcze chełpiły się podlaskie gospodynie, powędrowało na dno kufra, ustępując miejsca tandecie i bezguściu.

Około połowy ubiegłego wieku drewniane ściany kuchni, alkierza i izby reprezentacyjnej zazwyczaj bielono, później oklejano wzorzystym papierem. Na początku lat siedemdziesiątych zaczęto masowo osłaniać je płytą pilśniową, malowaną następnie farbą olejną, i zdobić nadrukiem jednobarwnych, przeważnie geometrycznych szlaczków oraz narożnych motywów florystycznych. Na ścianach wiejskich chałup zawisły prymitywne obrazki pejzażowe, a nad łóżkami nadruki pseudomakatkowe. Motywem przewodnim była para jeleni, nienaturalnych rozmiarów postacie kobiece, ptaki, zawsze z zachowaniem symetrii i lustrzanego odbicia we wzorach. Już w okresie międzywojennym kanoniczne ikony zastąpiły oleodruki, a na początku lat 70 . XIX wieku pojawiły się kupowane u wędrownych handlarzy obrazy o tematyce religijnej, w ujęciu plastycznym, które trudno nazwać sakralnym. Do kanonu wiejskiej mody, określającego wystrój głównej izby, weszły, oferowane przez rzemieślników, fotografie ślubne i dzieci, które po nieumiejętnej obróbce (pokolorowaniu i pseudoretuszu), często nie przypominały oryginałów. Naśladowanie miejskich trendów, z punktu widzenia dotychczasowej wiejskiej estetyki, okazało się niekorzystne i obce, wprowadzając bylejakość w wystroju wiejskich wnętrz. Zmiany te spowodowały zarzucenie tradycyjnego zdobnictwa. Do lamusa powoli odchodziły ręczniki, papierowe firanki, makatki, płachty, chodnik.

\section{Stroje kobiece}

O pozycji, gospodarności czy wreszcie zamożności wiejskiej kobiety i jej rodziny świadczyło nie tylko wnętrze domu, ale i jej garderoba, zaspokajające także poczucie estetyki. Strój kobiecy szyty był z lnianego lub wełniane- 
go samodziału, z dekoracyjnymi ornamentami. W okresie międzywojennym stosowano już także materiały fabryczne. Wyjściowym strojem kobiecym były spódnice, tzw. sajany, tkane z wełny, krojone z ukosa, co dawało efekt rozkloszowania, zdobione zazwyczaj trzema rzędami jednobarwnych przeważnie czarnych tasiemek bądź zaprasowanych plis, co podnosiło ich szyk. Nicie barwiono naturalnymi barwnikami. Z czasem zaczęto stosować domowym sposobem farby fabryczne, rozszerzając paletę barw. Sajany szyto z sukna w ciemnych odcieniach zieleni, fioletu, granatu, brązu, borda, rzadko czerni. Ciepłą porą roku kobiety nosiły tzw. parciaki, w których dekoracyjny był już sam materiał, tkany w kratkę, podłużne czy poprzeczne pasy bądź jednolity. Te były szyte z paru kawałków, przymarszczane w talii w wąską opaśnicę. Dopełnieniem spódnicy były fartuszki (zapaski), proste zakładane na co dzień i zdobione od święta, szyte z lnianego płótna własnej roboty lub z fabrycznego materiału, ozdabiane na kilka sposobów - haftem krzyżykowym, wzorem atłaskowym, koronką, marszczoną plisą. Fartuszki to bardzo charakterystyczna część garderoby podlaskich kobiet, noszona zarówno przez panny, mężatki, jak i sędziwe kobiety. W formie ciekawostki warto zauważyć, że miniaturowe fartuszki wieszano na krzyże na grobach zmarłych kobiet.

Starsze koszule kobiece, podobnie jak i męskie, zdobione były czerwono-czarnym haftem krzyżykowym na stójce (później zastąpionej przez kołnierz) i mankietach. Rozpinane z przodu, wyróżniały się charakterystycznym reglanowym rękawem, w powojennych stosowano już krój rękawa z wszytą główką. Podobnie haft krzyżykowy zastąpiono barwnym atłaskowym. Bluzki, zwane tu kaftanami, wpuszczano w spódnicę, kobiety nie nosiły ich po wierzchu. Obok koszul tradycyjnie zdobionych w okresie międzywojennym zaczęto szyć z fabrycznych materiałów. Zanim pojawiły się pedałowe maszyny krawieckie, w użyciu były ręczne. Wcześniej kobiety szyły bieliznę i ubrania wierzchnie ręcznie. Dekoracyjny dodatek kobiecej garderoby stanowiły barwne, szklane guziczki o wyglądzie paciorków.

Jesienią i wiosną kobiety nosiły tzw. paltka, półpaltka, z sukna własnej roboty, bądź materiałów fabrycznych, przeważnie pluszu, niekiedy dodawano naturalny kołnierz barani bądź ze skóry będących zmorą wiejskich gospodyń stałych bywalców kurników - tchórzy. Zimową porą zakładano kożuchy. Żeńskie kożuszki były krótkie w porównaniu do męskich i barwione przez miejscowych garbarzy w korze dębowej na kolor żółto-brązowy, z dużym wykładanym kołnierzem z szarego bądź czarnego owczego futra, podobnie obszywano u dołu $z$ przodu i na kieszeniach. Bogato je dekorowano, wyszywając kolorowym subtelnym haftem, krzyżyko- 
wym, jodełkowym, gałązkowym i błyszczącym czarnym lub brązowym rzemykiem ${ }^{4}$.

Dopełnieniem kobiecego stroju, niezależnie od pory roku, była samodziałowa chustka, lniana lub wełniana, w okresie międzywojennym fabryczna tzw. batystówka, przeważnie biała, ale i w pastelowych kolorach, wiązana z przodu pod szyją. Zakładały je zarówno panny, jak i mężatki. Zimą bogatsze kobiety nosiły wełniane chustki kupowane, o pięknych wzorach i pastelowej kolorystyce, później nauczyły się same robić na drutach, naśladując fabryczne. Po wojnie pojawiły się kwieciste, wełniane szelanówki. Chłodną porą kobiety otulały się dużymi, wełnianymi we wzorzystą kratę, chustami wyrobu fabrycznego bądź własnego.

W garderobie wiejskiej kobiety buty stanowiły spory wydatek. Latem zakładano krótkie trzewiczki na niskim obcasiku, a chłodną porą trzewiki z cholewkami, zarówno jedne jak i drugie były sznurowane z przodu. Do świątyni czy na targ do miasta nawet największe wiejskie modnisie najczęściej wędrowały boso. Dopiero u kresu podróży myto czy wycierano mokrą szmatą nogi i zakładano trzewiki. Zimą noszono bite z owczej wełny walonki, które osłaniały gumowe kalosze.

Warto wspomnieć o ślubnych strojach. Jeszcze w okresie międzywojennym panny młode zakładały sukienki kolorowe w pastelowych przeważnie odcieniach, które ze względu na ubóstwo nosiły potem wielokrotnie jako strój odświętny. Wcześniej na wsi nie noszono sukienek, a spódnicę, kaftan, koszulę. Muzeum posiada dwie długie suknie o skromnym kroju, szyte z bardzo delikatnego lnianego samodziału. Podobnie welon - jego tradycja w tej części podlaskich wsi sięga końca lat 30. ubiegłego wieku. Był on skromny, ale aż ciągnący się po ziemi. Dekoracyjnie zebrany jeden koniec upinano na kształt nimbu z przodu głowy, przyozdabiając gałązkami mirtu, asparagusa, kwiatami. Do końca lat 20. głowę panny młodej przyozdabiały wplatane we włosy wstążki.

Ciekawą i godną odnotowania inicjatywą nawiązującą do tradycji dawnego zdobnictwa jest przedsięwzięcie Magdaleny Pietruk, która stosuje etnodesign. Tworzy, głównie z naturalnych materiałów (lnu i wełny), kolekcje inspirowane podlaskim folklorem, czerpiąc wzory i techniki zdobnicze z ludowego rękodzieła ${ }^{5}$.

4 A. Troc-Sosna, Бацькаўшчына. Muzeum Kultury Materialnej w Rybolach, Ryboły-Studziwody 2011, s. 72.

5 Xoroshe, „Czasopis” 2014, Nr 10, s. 27-30. 


\section{Konkluzja}

Płótna i sukna, tkane przez podlaskie gospodynie, były wdzięcznym materiałem dekoracyjnym, którym nie pogardzili by i współcześni projektanci mody. Faktura samodziału, niezwykle bogate i barwne zdobnictwo, ciekawe kroje, zachwycaja wysokim kunsztem prac tkackich, hafciarskich i koronkarskich, poczuciem estetyki, wrażliwością na piękno. Podejście do tematu autorek rękodzieła ujmuje artystycznym widzeniem przyrody (dominujące elementy flory i fauny), w zgodzie z którą toczyło się życie dawnej wsi, podporządkowując się jej prawom. Zadumą napawa symboliczne pojmowanie otaczającego świata, zaczerpnięte z niepisanego kodeksu wiejskiej moralności ponadczasowe mądrości, takie, jak miłość bogobojność, wierność, zgoda. Pomimo że nigdy nie praktykowano sztywnego kanonu, który ograniczał by inwencje twórcze, to jednak wypracowano pewne charakterystyczne detale. W elementach dekoracyjnych odnajdujemy echa dalekiej przeszłości, wyrażone w symbolice, nawiązującej do mitologii przodków. Nieobce są uniwersalne elementy, które cechują chłopskie arcydzieła, będące wytworem paru pokoleń podlaskich kobiet.

\section{Л I T A P A T Y P A}

Лабачэўская В., Повязь часоў - беларускі ручнік, Мінск 2002.

Фадзеева Б., Беларускі руинік, Мінск 1994.

Xoroshe, „Czasopis” 2014, Nr 10.

Troc-Sosna A., Бацькаўщчьна. Mиzеuт Kultury Materialnej w Rybolach, Ryboły-Studziwody 2011.

РЭЗ М

ДЭКАРАЦЫЙНЫЯ НАКІРУНКІ ПАДЛЯСКІХ СТРОЯЎ І ТКАНІН, УЖЫВАНЫХ У ПЕРШАЙ ПАЛОВЕ ХХ СТАГОДДЗЯ, НА БАЗЕ МУЗЕЙНЫХ ЗБОРАЎ "БАЦЬКАЎШЧЫНЫ"

У арганізаваным айцом і матушкай Соснамі Музеі "Бацькаўшчына" у Рыбалах сабраны багаты збор, які датычыцца штодзённага жыцця мясцовых беларусаў. Ручныя вырабы даюць магчымасць выказацца аб іх знешнім выглядзе. Узніклі характэрныя арнамент і аздабленне сялянскіх строяў, асабліва жаночых, і арыгінальныя дэкарацыйныя тканіны. Казачныя каляровыя ручнікі, дыванкі, накідкі, абрусы, пасцель і дробныя дэталі дэкору хат дасюль захойваюць мастацкую своеасаблівасць. Дэкарацыйныя тканіны надавалі 
святочнасць і шматфарбнасць сялянскаму жыллю. У выпадку дэкарацыйных тканін і строяў стасаваліся падобныя накірункі і тэхнікі аздаблення, ад гафту крыжыкавага праз гафт атласны да мярэжкі і гафту рышэлье. Фактура саматканак, незвычайна багатае і каляровае аздабленне, цікавыя фасоны дасюль захапляюць высокім майстэрствам і адчуваннем прыгажосці іх стваральнікаў.

Ключавыя словы: аздабленне, тэхнікі аздаблення, дэкарацыйныя тканіны, ручнік, абрус, дыванок.

\section{S U M M A R Y}

\section{DECORATIVE TRENDS OF PODLASIE OUTFIT AND TRADE FABRIC \\ IN THE FIRST HALF OF THE 20TH CENTURY BASED ON MUSEUM COLLECTION BAĆKAUSZCZYNA}

Baćkauszczyna museum opened by an Orthodox priest Sosna and his wife in Ryboly has a rich collection of everyday objects that belonged to local Belarusians. Handwork made it possible to perceive objects as visually appealing creations. Peasant attire made from unique decorative fabrics had a specific design and adornment. Fabulous colorful towels, ornamental mats, coverlets, tablecloths, linen, and small details of the decor have been an object of fascination. Tapestry introduced glamour and color into peasant interior. Similar trends and embroidery techniques such as cross-stitch, fishnet stitch, hemstitch and richelieu stitch were used for both tapestry and outfit. Today people are delighted with the texture of homespun cloth, rich and colorful adornment, interesting cuts.

Key words: adornment, techniques of decorative arts, towels, ornamental mat. 